\title{
Evaluation of Clinical Features and Treatment Responses in Patients With Chronic Myeloid Leukemia: A Single Center Experience
}

\section{Kronik Myeloid Lösemi Tanılı Hastaların Klinik Özellikleri ve Tedaviye Yanıtlarının Değerlendirilmesi: Tek Merkez Deneyimi}

\author{
Mesut GÖÇER ${ }^{1}$ (D), Erdal KURTOĞLU ${ }^{1}$ (D) \\ ${ }^{1}$ Antalya Training and Research Hospital, Department of Internal Medicine, Division of Hematology, Antalya, TURKEY
}

\section{Abstract}

Background: Chronic myeloid leukemia is a clonal hematopoietic stem cell disorder that leads to an increase in myeloid cells, erythroid series, and platelets in peripheral blood and causes pronounced myeloid hyperplasia in the bone marrow. The treatment and follow-up criteria in patients with CML have changed significantly in the recent years. In the pre-imatinib period, CML has been treated with hydroxyurea, interferon therapy, chemotherapy, and most effectively, allogenic stem cell transplantation. The addition of imatinib mesylate, a tyrosine kinase inhibitor, to the treatment regime provided a superior overall survival rate compared to previous standard treatments. In this study, our aim is to demonstrate the demographic characteristics, clinical features, treatment and follow-up strategies, response status, and general survival rates of CML patients treated in our clinic.

Materials and Methods: 110 patients who were diagnosed with chronic phase CML during 2003-2019 were included in this study. The demographic characteristics and clinical findings including laboratory values, ultrasound findings, and bone marrow pathology results were evaluated retrospectively from their medical records

Results: Among the 110 patients included, 59 (53.6\%) were male, and 51 (46.4\%) were female, and the median age was 49.5 (18-82). At the time of diagnosis, only 32 (29.0\%) patients were symptomatic, 71 (64.5\%) had splenomegaly, and 51 (46.4\%) had hepatomegaly. All patients were given $400 \mathrm{mg}$ of imatinib as first-line therapy. With imatinib treatment, the rates of complete hematologic response (CHR), complete cytogenetic response (CyCR), and major molecular response (MMR) were $100.0 \%, 72.5 \%$ and $69.6 \%$, respectively. In the follow-up, 3 (2.7\%) patients were observed to progress to the blastic phase. The overall survival rate was $86.4 \%$.

Conclusions: Imatinib has proven to be a tolerable, effective and safe agent in the first-line treatment of CML patients. Treatment choice after imatinib should take into consideration the patients' comorbidities.

Key Words: Chronic myeloid leukemia, Tyrosine kinase; Treatment response

Öz.

Amaç: KML periferik kanda miyeloid hücreler, eritroid seri ve trombositlerin artmasına yol açan, kemik iliğinde de belirgin miyeloid hiperplazisine neden olan klonal hematopoetik bir kök hücre hastalığıdır. KML tanılı hastaların tedavi ve takip kriterleri son yıllarda önemli oranda değişmiştir. İmatinib öncesi dönemde KML hidroksiüre, interferon, kemoterapi ve en etkili şekilde de allojenik kök hücre nakli ile tedavi edilmiştir. Tirozin kinaz inhibitörü imatinib mesilatın tedaviye eklenmesi önceki standart tedavilere kıyasla daha üstün bir genel sağ kalım sağlamıştır. Bu çalışmadaki amacımız, kliniğimizde tedavi edilen KML hastalarının demografik özelliklerini, klinik özelliklerini, tedavi ve izleme stratejilerini, yanıt durumlarını ve genel sağ kalım oranlarını belirlemektir. Materyal ve Metod: 2003 ve 2019 tarihleri arasında kronik faz KML tanısı koyulan ve dosya kayıtlarına ulaşılabilen 110 hasta çalışmaya dahil edildi. Hastaların demografik özellikleri, klinik bulguları, laboratuvar değerleri, ultrasonografi bulguları ve kemik iliği patoloji sonuçları değerlendirildi.

Bulgular: 110 tane hastanın 59 (\%53.6) tanesi erkek, 51 (\%46.4) tanesi kadındı. Tanı anındaki medyan yaş 49.5 (18-82) saptandı. Tanı anında sadece 32 (\%29.0) hasta semptomatikti. Hastaların tanı anında 71 (\%64.5) tanesinde splenomegali ve 51 (\%46.4) tanesinde hepatomegali vardı. Tüm hastalara ilk basamakta imatinib 400 mg verilmişti. İmatinib tedavisi ile 12. ayda THY oranı \%100, TSY oranı \%72.5 ve MMR oranı ise \%69.6 saptandı. Takiplerde 3 (\%2.7) hastanın blastik faza progrese olduğu görüldü. Tüm hastaların OS oranı \%86.4 saptandı. Sonuç: KML hastalarının ilk basamak tedavisinde imatinib tolere edilebilir, etkili ve güvenli bir ajan olduğunu kanıtlamıştır. İmatinib sonrası tedavi değişikliği yapılırken hastaların komorbiditeleri göz önünde bulundurulmalıdır.

Anahtar kelimeler: Kronik myeloid lösemi, Tirozin kinaz; Tedavi yanıtı
Corresponding Author / Sorumlu Yazar

Dr. Mesut GÖÇER

Antalya Training and Research Hospital, Department of Internal Medicine, Division of Hematology, Antalya, 07100, TURKEY

E-mail: gocermesut@gmail.com

Received / Geliş Tarihi: 04.01.2021

Accepted / Kabul Tarihi: 09.02.2021

DOI: $10.35440 /$ hutfd. 853074 


\section{Introduction}

Chronic myeloid leukemia (CML) is a myeloproliferative neoplasm characterized by irregular production and uncontrolled proliferation of the granulocytic cell line without losing its differentiation capacity (1). It is a clonal hematopoietic stem cell disorder that causes significant myeloid hyperplasia in the bone marrow (1). In addition to the increase in myeloid cells in peripheral blood, it may lead to an increase in the number of erythroid series and platelets. The incidence of $\mathrm{CML}$ increases in adulthood and it constitutes $15 \%-20 \%$ cases of leukemia in this period (2). CML is characterized by $t$ (9:22) translocation that generates the $B C R-A B L$ fusion gene, a specific cytogenetic abnormality (3). The translocation $t(9 ; 22)$ (q34; q11), known as the Philadelphia (Ph) chromosome, occurs as a result of the fusion of the Abelson proto-oncogene (ABL1) on chromosome 9 and the Break point cluster region (BCR) gene on chromosome 22 (4). Compared to the normal $A B L$ gene, the BCR-ABL1 hybrid gene results in the synthesis of a chimeric fusion protein with high tyrosine kinase activity (5). Oncogenic BCR-ABL1 proteins affect cell proliferation, adhesion, migration, and DNA repair mechanisms by altering several signal pathways (6). Typical clinical presentation of $\mathrm{CML}$ has 3 different clinical phases: chronic, accelerated and blastic phases (7). Most patients are diagnosed in the chronic phase (8). If not treated appropriately, newly diagnosed chronic phase CML patients may progress to the accelerated phase and finally to the blastic phase. Among all clinical phases, the blastic phase of the disease has a poor prognosis, i.e., very short survival periods of 3-6 months (9). Initial symptoms in chronic phase $\mathrm{CML}$ are usually insidious, and $\approx 30 \%$ of patients are asymptomatic (10). Symptoms in CML often appear due to anemia and splenomegaly. The most common symptoms in the chronic phase include weakness, pallor, appetite and weight losses, and a feeling of abdominal distension/fullness.

CML diagnosis includes peripheral blood and/or bone marrow examination, accompanied by checking for the presence of $\mathrm{Ph}$ chromosome in karyotype or the detection of the BCR-ABL fusion gene either by fluorescent in situ hybridization (FISH) or polymerase chain reaction (PCR) method (11). The most important finding in peripheral blood smear analysis is neutrophilic leukocytosis and basophilia. Although leukocytosis is predominantly neutrophilic, all developmental stages of the granulocytic series can be observed in peripheral blood, from myeloblasts to segmented neutrophils (10). To date, various scoring systems have been identified to predict the disease prognosis among which sokal scoring system is one of the most commonly used. In this scoring system, age, blast percentage, spleen size, and high platelet count are included in the scoring (12).

There has been a rapid change and development in $\mathrm{CML}$ treatment in the last 30 years. In the pre-imatinib period, the commonly used treatment modalities for CML included treatment with hydroxyurea (HU), interferon therapy, chemotherapy, and most effectively, allogenic stem cell transplantation. The use of imatinib mesylate and tyrosine kinase inhibitor (TKI), which specifically targets tyrosine kinase activity, provided a superior overall survival (OS) progression-free survival rate compared to previous standard therapies (13). Second generation TKIs developed after imatinib (nilotinib and dasatinib) are more potent in inhibiting the BCR-ABL oncoprotein. They can be used instead of imatinib as a first-line treatment option for chronic phase CML. Two large randomized trials, ENESTnd and DASISION, showed that second generation TKIs are more effective in achieving optimal responses than imatinib $(14,15)$. It is important to select the most appropriate TKI to minimize the risk of progression at the time of diagnosis while also minimizing treatment-related toxicity. Our aim in this study is to provide the demographic characteristics, clinical features, treatment and follow-up strategies, response status and general survival rates in CML patients treated in our clinic.

\section{Materials and Methods}

In this single-center retrospective observational study, 110 patients who were diagnosed with chronic phase CML between 2003 and 2019 and with medical records were included. In addition to the demographic characteristics of the patients, clinical features, laboratory values, ultrasonography findings and bone marrow pathology results at the time of diagnosis were evaluated.

Hematological response was defined as follows: normalization of leukocyte and platelet counts, $<5 \%$ total myelocyte and metamyelocyte count in peripheral blood smear, no detection of blast and promyelocytes, no extramedullary involvement, no findings of accelerated and blastic phase within 3 months after the initiation of treatment. Molecular responses of the patients to the treatment were evaluated by real time polymerase chain reaction (real time PCR) at 3, 6, and 12 months. BCR-ABL1 transcript levels of $10 \%$ at 3 months, $<1 \%$ at 6 months, and $0.1 \%$ from 12 months were defined as optimal response. Cytogenetic response control was evaluated by investigating the results of conventional cytogenetic examination and/or FISH method performed with bone marrow aspiration material obtained $\geq 12$ months of treatment. Complete cytogenetic response was defined as a $\mathrm{Ph}(+)$ metaphase count of $0 \%$. In statistical analysis, the data was presented as number, percentage, mean, and median. The mean survival duration of the patients was calculated with Kaplan-Meier curves. Factors affecting OS duration were examined by the univariate Cox regression model. SPSS 22.0 program was used in the calculations. 


\section{Results}

Among the 110 patients included in the study, 59 (53.6\%) were male and 51 (46.4\%) were female. The demographic characteristics of patients are summarized in Table-1. The median age of the patients at the time of initial diagnosis was 49.5 (18-82), while the median age at the last followup was 56 . The median follow-up period of the patients was 69.5 (11-209) months. At the time of diagnosis, 32 $(29.0 \%)$ of the patients had symptoms. Based on the evaluation of the sokal risk score at the time of diagnosis, 46 $(41.8 \%)$ patients were found to be at high risk. With regard to comorbidities, 12 (10.9\%) patients had diabetes mellitus, 8 (7.2\%) had hypertension and $6(5.4 \%)$ had coronary artery disease. Imatinib (400 mg) was administered to all diagnosed patients as first-line therapy. Prior to treatment with imatinib, 61 (55.5\%) of the patients were treated with hydroxyurea. Among the 110 patients, 95 (86.4\%) were alive and had regular follow-up while 15 (13.6\%) patients died due to disease-related or unrelated reasons. OS curves of the patients are shown in Figure-1. When the recent treatment status of the patients was evaluated, 57 $(60.0 \%)$ of them were receiving first-line, 28 (29.4\%) were receiving second-line and $8(8.4 \%)$ were receiving thirdline treatment, while $2(2.2 \%)$ of them were followed up without medication. One of the patients who were followed up without medication discontinued the treatment after the first-line treatment and the other after the fourth stage.

Table 1. Demographic and clinical features of the patients

\begin{tabular}{|c|c|}
\hline & $\mathrm{n}=110(100 \%)$ \\
\hline Age, median & $56(20-85)$ \\
\hline Age of Diagnosis, median & $49.5(18-82)$ \\
\hline \multicolumn{2}{|l|}{ Sex, n (\%) } \\
\hline Female & $51(46.4)$ \\
\hline Male & $59(53.6)$ \\
\hline \multicolumn{2}{|l|}{ Presence of Symptoms at Diagnosis, (\%) } \\
\hline Yes & $32(29.0)$ \\
\hline No & $78(71.0)$ \\
\hline \multicolumn{2}{|l|}{ Social Risk Score, n (\%) } \\
\hline Low & $27(24.5)$ \\
\hline Medium & $37(33.7)$ \\
\hline High & $46(41.8)$ \\
\hline Follow-up Period, median month & $69.5(11-209)$ \\
\hline Use of hydroxyurea before imatinib, $n$ (\%) & $61(55.5)$ \\
\hline \multicolumn{2}{|l|}{ Final Treatment Status, $\mathrm{n}(\%)$} \\
\hline First line & $57 / 95(60.0)$ \\
\hline Second line & $28 / 95(29.4)$ \\
\hline Third line & $8 / 95(8.4)$ \\
\hline Drug-free follow-up & $2 / 95(2.2)$ \\
\hline \multicolumn{2}{|l|}{ Survival Status, $\mathrm{n}(\%)$} \\
\hline Alive & $95(86.4)$ \\
\hline Dead & $15(13.6)$ \\
\hline
\end{tabular}

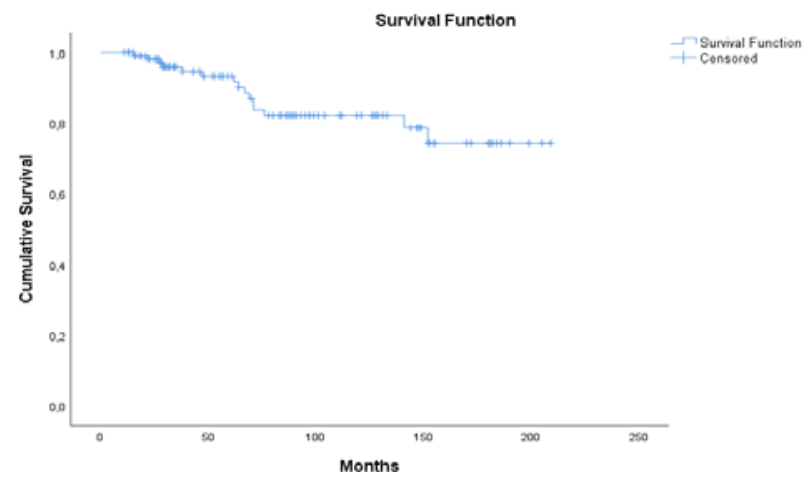

Fig 1. Overall survival analyses for all patients with the diagnosis of $\mathrm{CML}$

Bone marrow biopsies showed that 33 (30.0\%) of the patients had fibrosis. Evaluation of bone marrow cellularity revealed that $2(1.8 \%)$ of the patients were hypocellular, 5 (4.5\%) normocellular, and 103 (93.6\%) hypercellular. In the initial diagnosis, 71 (64.5\%) patients had splenomegaly, and 51 (46.4\%) had hepatomegaly. The median size of spleen evaluated by ultrasonography was 156.5 (95-270) $\mathrm{cm}$, and the median liver size was $146.5(117-235) \mathrm{cm}$. Responses to imatinib treatment given to all patients as firstline treatment are summarized in Table3. Complete hematological response (CHR) was achieved in 95/110 (86.4\%) patients at 3 months, $105 / 110(95.4 \%)$ patients at 6 months, and 102/102 (100\%) patients at 12 months. Major molecular response (MMR) was observed in 14/110 (12.7\%) patients at 3 months, 44/110 (40.0\%) patients at 6 months and 71/102 (69.6\%) patients at 12 months. A bone marrow biopsy was made, and cytogenetic analysis was performed at the $12^{\text {th }}$ month in patients who continued imatinib treatment. A complete cytogenetic response (CCyR) was observed in 74/102 (72.5\%) patients at 12 months. Due to primary resistance in 20 patients and secondary resistance in 24 patients, a total of 44 (40\%) patients were switched to second-line treatment. The median time to switch to a second-line treatment was 27.5 (6-118) months. Nilotinib was used in 21 (47.7\%) patients and dasatinib in $23(52.3 \%)$ patients for second-line therapy. Because of the development of primary resistance in $4(19.0 \%)$ of 21 patients using nilotinib, secondary resistance in $1(4.7 \%)$ and side effects (acute pancreatitis) in $1(4.7 \%)$, the third-line treatment was initiated. The thirdline treatment was initiated due to the development of primary resistance in $1(4.1 \%)$, secondary resistance in 2 (8.3\%) and side effects (pleural effusion) in 4 (16.6\%) of 24 patients who were on dasatinib. Dasatinib was started as third-line treatment in patients receiving nilotinib as second-line treatment, and vice versa. The median time to switch to third-line therapy was 29.5 (10-130) months. Bosutinib was started as fourth line therapy in 1 patient; however, the patient could not tolerate the drug, and the treatment was discontinued. It was found that $3(2.7 \%)$ atients progressed to the blastic phase during their followup. 
Table 2. Laboratory, pathology and ultrasonography results of patients

\begin{tabular}{|c|c|}
\hline Leukocytes $10^{3} / \mathrm{mm}^{3}$; median & $88600(14600-527400)$ \\
\hline Hemoglobin g/L; median & $10.4(5.5-15.7)$ \\
\hline $\mathrm{MCV} \mu \mathrm{m}^{3} ;$ median & $86(57-106)$ \\
\hline Hematocrit & $32.2(17.3-48.6)$ \\
\hline Platelet $10^{3} / \mathrm{mm}^{3} ;$ median & $459000(95000-4975000)$ \\
\hline \multicolumn{2}{|l|}{ Fibrosis in the Bone Marrow; $\mathrm{n}(\%)$} \\
\hline Yes & $33 / 110(30.0)$ \\
\hline $\mathrm{No}$ & $77 / 110(70.0)$ \\
\hline \multicolumn{2}{|l|}{ Bone Marrow Cellularity; $\mathrm{n}(\%)$} \\
\hline Hypocellular & $2 / 110(1.8)$ \\
\hline Normocellular & $5 / 110(4.5)$ \\
\hline Hypercellular & $103 / 110(93.6)$ \\
\hline Splenomegaly at the Time of Diagnosis; $\mathrm{n}(\%)$ & $71 / 110(64.5)$ \\
\hline Spleen size $\mathrm{cm}$; median & $156.5(95-270)$ \\
\hline Hepatomegaly at the Time of Diagnosis; $\mathrm{n}(\%)$ & $51 / 110(46.4)$ \\
\hline Liver Size cm; median & $146.5(117-235)$ \\
\hline
\end{tabular}

Table 3. Hematologic, molecular and cytogenetic response rates of CML patients to imatinib treatment.

$\begin{array}{lccc} & \text { 3.Months } & \text { 6.Months } & \text { 12.Months } \\ \text { CHR } & 95 / 110(86.4) & 105 / 110(95.4) & 102 / 102(100.0) \\ \text { MMR } & 14 / 110(12.7) & 44 / 110(40.0) & 71 / 102(69.6) \\ \text { CCyR } & - & - & 74 / 102(72.5)\end{array}$

CHR: complete hematologic response, MMR: major molecular response, CCyR:complete cytogenetic response

\section{Discussion}

In this retrospective study, demographic characteristics, laboratory findings, treatment choices, treatment responses, and side effects related to treatment were evaluated in 110 patients followed up in a single center with a diagnosis of chronic phase CML. The mean age of the studied patients at the time of diagnosis was 49.5 (18-82) similar to other studies. While the mean age of the patients was 50 in the IRIS study and 46 in the ENESTnd study, it was found to be 46.1 in a multi-center study conducted in our country(16-18). It is known that CML is more common in men (19). This was supported by $61.7 \%$ of patients in the IRIS study and $56 \%$ in the ENESTnd study being male $(16,17)$. Similar to these studies, $53.6 \%$ of the patients were male in our study. In the study of the Turkish CML study group, the proportion of female patients $(50.7 \%)$ was minimally higher than that of men (18).

Symptoms and clinical manifestations of patients with CML may vary depending on the disease phase. In various studies, $\approx 50 \%$ of the patients were diagnosed with suspected routine blood tests during the asymptomatic period (20). Among symptomatic patients, the most common complaints were malaise, fatigue, and abdominal distension. In our study, only $29 \%$ of patients had symptoms at the time of diagnosis. As the patient's comorbidities increase, hospital admissions and blood count frequencies also increase. Considering all these, diagnosis can be made in the early period of the disease when patients are asymptomatic. Hepatomegaly and splenomegaly may be observed during physical examination in patients with CML. While the rate of hepatomegaly was found to be $46.5 \%$ in one study, that of splenomegaly was found to be $64.7 \%$ in another study $(18,21)$. Similar to these results, we determined the hepatomegaly and splenomegaly rates to be $46.4 \%$ and $64.5 \%$.

There have been major changes in the $\mathrm{CML}$ treatment over the years. First, cytoreductive agents (Hydroxyurea and Busulfan) were introduced in the treatment, and subsequently, biological response modifiers (interferons) were added. Allogeneic stem cell transplantation, which was previously the only curative treatment, is currently administered only to patients who are resistant to other treatments and young patients. Tyrosine kinase inhibitors imatinib, nilotinib, bosutinib, dasatinib, and ponatinib have replaced all these previous treatments in the treatment of CML. Due to the current reimbursement conditions in our country, imatinib is used for first-line treatment in all patients. In our study, we evaluated the hematological, molecular, and cytogenetic responses of the patients to imatinib treatment used as the first-line treatment. CHR rates were $86.4 \%$ at 3 months, $95.4 \%$ at 6 months and $100 \%$ at 12 months. In a study conducted in our country involving 1133 patients, the rate of CHR on imatinib was found to be $95.7 \%$, which is similar to our results (18).

According to the European Leukemia Network (ELN) recommendations, failure to achieve CCyR in the $12^{\text {th }}$ month on imatinib treatment is considered as a treatment failure. In our study, CCyR rate was found to be $72.5 \%$ in the analysis performed from bone marrow aspiration material at the $12^{\text {th }}$ month While the observed CCyR rate was $63.8 \%$ in the study by Şahin et al., it was $82 \%$ in the IRIS study. [18][13]. The MMR rate inpatients on imatinib treatment was $69.6 \%$ in our study. In a multi-center study by Lakhal et al., the MMR response rate in patients using imatinib was found to be $68.4 \%$, similar to our study (22). The high rates of CHR, CCyR, and MMR demonstrated by imatinib in first-line therapy prove its efficacy. In our study, 20 patients switched to secondary treatment because of primary imatinib resistance and 24 patients due to secondary imatinib resistance. None of our patients on imatinib treatment had to switch their medication due to side effects. In the study of Şahin et al., it was necessary to switch the treatment as a result of development of side effects or drug intolerance due to imatinib treatment in $\approx 9 \%$ of the patients [18]. All these results show that imatinib has an acceptable potential for side effects in first-line treatment.

In our study, we found that the patient distribution for dasatinib (23 patients) and nilotinib (21 patients) in secondline treatment was similar. Their efficacy could not be compared because data was insufficient. Treatment was discontinued in 4 (16.6\%) patients receiving dasatinib due to pleural effusion and in 1 (4.7\%) patient receiving nilotinib due to acute pancreatitis.

It is known that chronic phase CML patients may progress to an accelerated or blastic phase at a rate of $1 \%-1.5 \%$ each year during their follow-up (23). In our study, during follow-up, we found that $3(2.7 \%)$ patients progressed to blastic phase. 
The most important limitation of our study is that the patient population receiving second-line treatment is not very large, and there is insufficient data in terms of treatment responses in this group. Apart from that, we believe that it is a study with a sufficiently high number of patients as a single center experience. In conclusion, in our study in which we evaluated patients who were followed up and treated with a diagnosis of $\mathrm{CML}$, it was seen that imatinib was a safe and effective therapeutic agent in first-line treatment. When the treatment is to be switched, the appropriate $2^{\text {nd }}$ generation TKI should be chosen, considering the comorbidities of the patients.

Ethical Approval: Approval was obtained from the hospital management and Antalya Training and Research Hospital Ethics Committee (protocol number/date: 16-20/22.10.2020) to use patient data. The study was conducted according to the ethical principles of the Helsinki Declaration.

Author Contributions: Concept: MG; Literature Review: MG, EK Design: MG; Data acquisition: MG, EK; Analysis and interpretation: MG, EK; Writing manuscript: MG; Critical revision of manuscript: $M G, E K$

Conflict of Interest: Authors declared no conflict of interest. Financial Disclosure: Authors declared no financial support.

\section{References}

1. Sawyers CL. Chronic myeloid leukemia. Vol. 340, New England Journal of Medicine. Massachusetts Medical Society ; 1999. p. 1330-40.

2. Goldman JM, Melo J V. Mechanisms of disease: Chronic myeloid leukemia - Advances in biology and new approaches to treatment. Vol. 349, New England Journal of Medicine. Massachusetts Medical Society ; 2003. p. 1451-64.

3. Corm S, Roche L, Micol JB, Coiteux V, Bossard N, Nicolini $\mathrm{FE}$, et al. Changes in the dynamics of the excess mortality rate in chronic phase-chronic myeloid leukemia over 1990-2007: A population study. Blood 2011;118(16):4331-7.

4. Groffen J, Stephenson JR, Heisterkamp N, de Klein A, Bartram CR, Grosveld G. Philadelphia chromosomal breakpoints are clustered within a limited region, bcr, on chromosome 22. Cell. 1984;36(1):93-9.

5. Davis RL, Konopka JB, Witte ON. Chromosomal Translocation Generates Altered c-abl Proteins with Similar In Vitro Kinase Properties. Vol. 5, MOLECULAR AND CELLULAR BIOLOGY. 1985.

6. Ren R. Mechanisms of BCR-ABL in the pathogenesis of chronic myelogenous leukaemia. Vol. 5, Nature Reviews Cancer. Nature Publishing Group; 2005. p. 172-83.

7. Vardiman JW. Chronic Myelogenous Leukemia, BCRABL1+. Am J Clin Pathol. 2009;132:250-60.

8. Steinberg M. Dasatinib: A tyrosine kinase inhibitor for the treatment of chronic myelogenous leukemia and philadelphia chromosome-positive acute lymphoblastic leukemia. Clin Ther. 2007 Nov 1;29(11):2289-308.

9. Sacchi $S$, Kantarjian HM, O'Brien S, Cortes J, Rios MB, Giles FJ, et al. Chronic myelogenous leukemia in nonlymphoid blastic phase: Analysis of the results of first salvage therapy with three different treatment approaches for 162 patients. Cancer. 1999;86(12):2632-41.
10. Savage DG, Szydlo RM, Goldman JM. Clinical features at diagnosis in 430 patients with chronic myeloid leukaemia seen at a referral centre over a 16-year period. Br J Haematol. 1997 Jan 1;96(1):111-6.

11. Tefferi A, Thiele J, Orazi A, Kvasnicka HM, Barbui T, Hanson $C A$, et al. Proposals and rationale for revision of the World Health Organization diagnostic criteria for polycythemia vera, essential thrombocythemia, and primary myelofibrosis: Recommendations from an ad hoc international expert panel. Blood. 2007;110(4):1092-7.

12. Sokal JE, Cox EB, Baccarani M, Tura S, Gomez GA, Robertson JE, et al. Prognostic discrimination in "good-risk" chronic granulocytic leukemia. Blood. 1984 Apr;63(4):789-99.

13. O'Brien SG, Guilhot F, Larson RA, Gathmann I, Baccarani $M$, Cervantes $F$, et al. Imatinib Compared with Interferon and Low-Dose Cytarabine for Newly Diagnosed ChronicPhase Chronic Myeloid Leukemia. N Engl J Med. 2003 Mar 13;348(11):994-1004.

14. Hughes TP, Saglio G, Kantarjian HM, Guilhot F, Niederwieser D, Rosti G, et al. Early molecular response predicts outcomes in patients with chronic myeloid leukemia in chronic phase treated with frontline nilotinib or imatinib. Blood. 2014;123(9):1353-60.

15. Jabbour E, Kantarjian HM, Saglio G, Steegmann JL, Shah $N P$, Boqué $C$, et al. Early response with dasatinib or imatinib in chronic myeloid leukemia: 3-year follow-up from a randomized phase 3 trial (DASISION). Blood. 2014;123(4):494-500.

16. Jabbour E, Kantarjian H. Chronic myeloid leukemia: 2018 update on diagnosis, therapy and monitoring. Am J Hematol. 2018 Mar 1;93(3):442-59.

17. Saglio G, Kim D-W, Issaragrisil S, le Coutre P, Etienne G, Lobo C, et al. Nilotinib versus Imatinib for Newly Diagnosed Chronic Myeloid Leukemia. N Engl J Med. 2010 Jun 17;362(24):2251-9.

18. Sahin F, Saydam G, Comert M, Uz B, Yavuz AS. Turkish Chronic Myeloid Leukemia Study: Retrospective Sectional Analysis of CML Patients. Turkish J Hematol. 2013;30(4):351-8.

19. Smith $A$, Howell $D$, Patmore $R$, Jack $A$, Roman $E$. Incidence of haematological malignancy by sub-type: $A$ report from the Haematological Malignancy Research Network. Br J Cancer. 2011;105(11):1684-92.

20. Faderl S, Talpaz M, Estrov Z, O'Brien S, Kurzrock R, Kantarjian HM. The Biology of Chronic Myeloid Leukemia. N Engl J Med. 1999 Jul 15;341(3):164-72.

21. Al-Amri AM. Outcome of Chronic Myeloid LeukemiaChronic Phase Patients Treated With Imatinib: A Local Experience. Clin Lymphoma, Myeloma Leuk. 2018;18(3):199-203.

22. Ben Lakhal $R$, Ghedira $H$, Bellaaj $H$, Ben Youssef $Y$, Menif $S$, Manai Z, et al. Chronic myeloid leukemia patients in Tunisia: epidemiology and outcome in the imatinib era (a multicentric experience). Ann Hematol. 2018;97(4):597604.

23. Hehlmann R. How I treat CML blast crisis. Blood. 2012;120(4):737-47. 